\title{
Using Various Types of Location Quotients to Disaggregate Turkey's Input-Output Table: An Application to the Production Structure of Region TR33
}

\author{
Fatih ÇELEBiOĞLU ${ }^{1}$ • Sandy DALL’ERBA ${ }^{2}$
}

\begin{abstract}
As many other developing countries, the statistical office of Turkey displays an input-output table at the national level only and it is not regularly updated. Yet, the need for regional-level information is growing because numerous publicly-funded development projects and private investments have taken place at the sub-national level over the recent years. In this paper we create an input-output table for one region, TR33, for the year 2014 by regionalizing and updating the national table through a location quotient approach. It allows us to calculate the regional employment and output multipliers across 33 sectors and to verify if their ranking varies across location quotient techniques. We expect our conclusions will help policy-makers and private investors take an informed decision when investing in TR33.
\end{abstract}

Key words: Input-Output, Location Quotient, Regional Development, Turkey, TR33

JEL Codes: C67, R11, R12, R15, R58

\section{INTRODUCTION}

Turkey is a country with large regional disparities of income (Gezici and Hewings, 2004; Celebioglu and Dall'erba, 2010). In order to address this issue, the central government decided to create NUTS-2 (Nomenclature of Territorial Statistical Units) regions in 2006 and to establish Regional Development Agencies (RDAs) that are expected to play a critical role in mobilizing support and funding for regional development projects (Lagendijk et al., 2009). Started with only two regions, İmir and Çukurova, the RDA scheme encompasses 26 agencies since 2009. The Zafer Development Agency is in charge of region TR33, the unit of analysis of this study. This region includes the provinces of Kütahya, Uşak, Afyonkarahisar and Manisa.

One of the main challenges that the State Planning Organization (SPO) and the RDAs regularly meet is the lack of regional level data to satisfy the demand for regional analysis. More precisely, in the absence of regional level input-output (I-O) tables, many RDAs turn to the Turkish Statistical Institute (Turk Stat) and its national level input-output table for their analysis. Even though that table is based on 2002 data at the national level, it has been used several times over the years. For instance, Çalışkan and Aydoğuş (2011) rely on it to determine and analyze the sources of industrial growth at the national level for the 1985-2002 period. They aggregate the 25 initial sectors into 8 sectors and show that export-led growth policies implemented after 1980 were mostly ineffective in the short run. However, they were relatively more effective in the long run at the cost of a higher import dependency in input use. For Tekin and Evcim (2011) the focus is on the relations between the agricultural sector and the other sectors of the national economy. They determine the cost (input) structure of the agricultural sector as well as its backward and forward linkages. More recently, Taşçı (2013) examine the structure of the ICT industry in the Turkish economy based on the two most recent national Input-Output tables (1998 and 2002).

Acknowledgements: This research was financially supported by the Scientific and Technological Research Council of Turkey (TUBITAK) with the project number 1059B191300514.

1fatih.celebioglu@uni-marburg.de

2dallerba@illinois.edu 


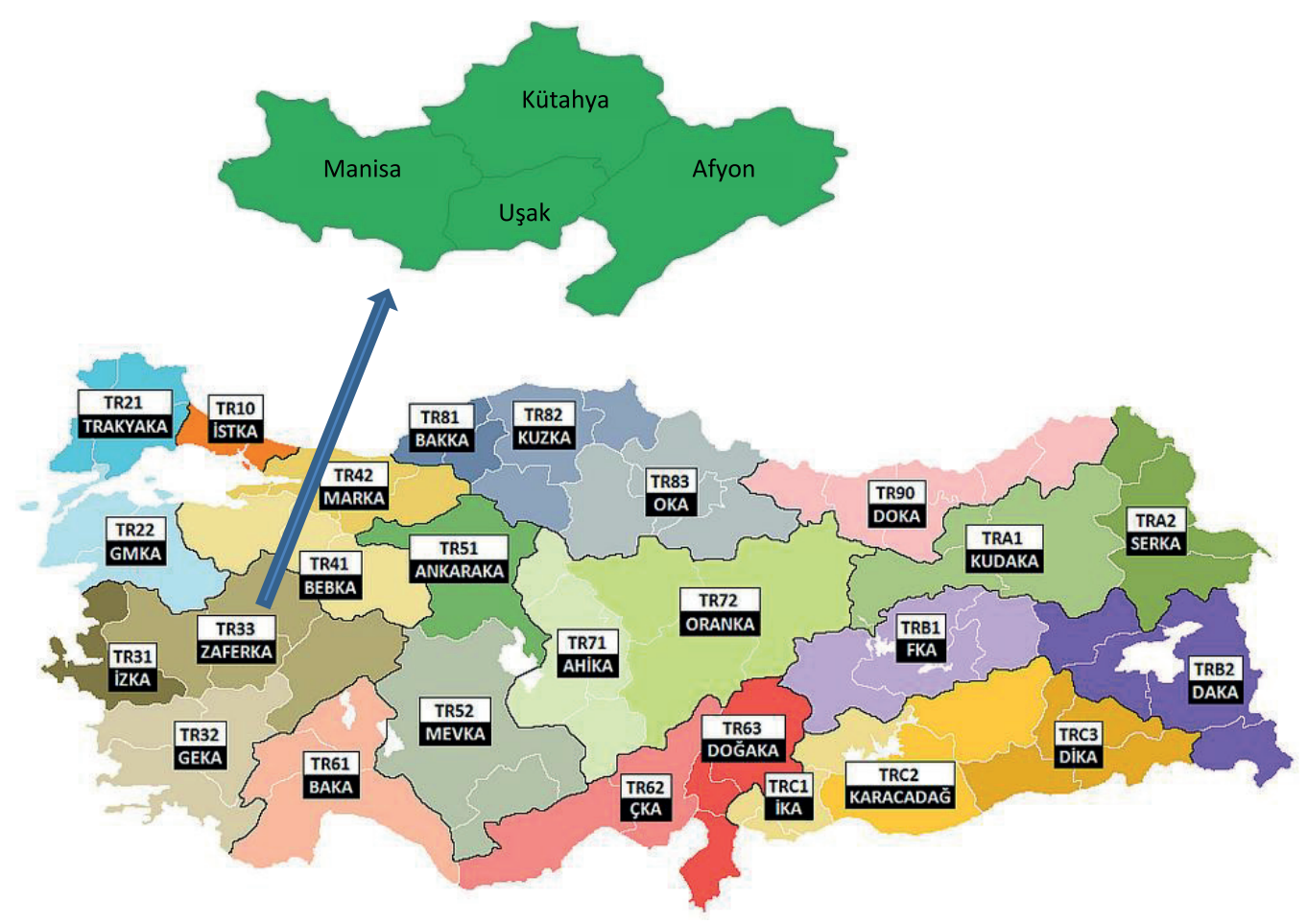

Figure 1: 26 Sub-Regions of Turkey (NUTS-2)

However, improvements in technology lead to changes in economic structure. In addition, there are obvious differences in the regional and national economic structures. These elements make the 2002 national table irrelevant for guiding the decision process of the private sector, public sector, NGOs, universities and other regional actors. For this reason, this paper offers a non-survey approach to regionalize and update the national I-O matrix to our region of interest. Even if the budget were available, we feel that a survey approach would only be partially effective because of the existence of a well-developed informal economy in Turkey (see for more details: Davutyan, 2008; Zengin and Tütüncü, 2016). In addition, we believe that small and medium sized enterprises would not display the real employment, income, and tax revenue figures.

To our knowledge, there has been only one previous attempt to build a regional level I-O table for this region. It is a report completed by the Zafer Regional Development Agency, ZEKA (2014) where the focus and conclusions are on the manufacturing industry. In our manuscript, we will present results for 33 economic sectors representing primary, secondary and tertiary activities. In addition, our aim is to generate a set of multipliers that can be compared across sectors to suggest regional economic policies. Because the magnitude of a multiplier varies with the type of location quotient (LQ) chosen in the regionalization of the national input-output table, the second objective consists in verifying if the ranking of the sectoral multipliers is sensitive to the LQ choice. The rest of the paper is organized as follows: section 2 provides a review of the 10 literature applied to economic development in Turkey. Section 3 describes the economy of TR33 and its structure while section 4 reviews the various types of location quotients that will be used in the analysis. Section 5 presents the figures associated to various types of multipliers in TR33. Finally, section 6 summarizes the most important results and offers some concluding remarks.

\section{LITERATURE ON REGIONAL LEVEL I-O ANALYSIS IN TURKEY}

Regional level I-O analyses are not numerous in Turkey and the bulk of such studies appeared after 2010. Table 1 below provides a summary of these studies. 
Table 1: Brief Literature on Regional Level I-O Analysis in Turkey

\begin{tabular}{|c|c|c|c|}
\hline Authors & Data & LQ (Location Quotient) Methods & Main Results \\
\hline $\begin{array}{l}\text { State Planning } \\
\text { Organization - SPO } \\
(2000)\end{array}$ & National I-O table of Turkey (1990). & Simple LQ and RAS (Richard A. Stone) & $\begin{array}{l}\text { Forward linkages, backward } \\
\text { linkages, employment multipliers } \\
\text { among the primary sectors of East } \\
\text { Anatolia }\end{array}$ \\
\hline Kaya (2006) & $\begin{array}{l}\text { Employment in manufacturing across } \\
26 \text { NUTS } 2 \text { regions }\end{array}$ & Simple LQ and LQ Index & $\begin{array}{l}\text { Changes in LQ in leading } \\
\text { manufacturing industries. }\end{array}$ \\
\hline Erdoğan (2011) & $\begin{array}{l}\text { Employment in two sectors ("rural" and } \\
\text { "industry \& services") and two regions } \\
\text { (East and West parts of Turkey) }\end{array}$ & Simple LQ and Social Account Matrix & $\begin{array}{l}\text { Final demand shock leads to } \\
\text { different output change in the } \\
\text { Easter and Western regions }\end{array}$ \\
\hline $\begin{array}{l}\text { İzmir Regional } \\
\text { Development Agency } \\
\text { (IZKA, 2012) }\end{array}$ & National IO Table of Turkey & $\begin{array}{l}\text { Partial survey method that includes } \\
\text { both survey and non-survey } \\
\text { methods. RAS algorithm }\end{array}$ & $\begin{array}{l}\text { Forward linkages, backward } \\
\text { linkages, multipliers (production, } \\
\text { income, employment, tax, and } \\
\text { import) for lzmir province. }\end{array}$ \\
\hline $\begin{array}{l}\text { West Black Sea } \\
\text { Development Agency } \\
\text { (BAKKA, 2014) }\end{array}$ & $\begin{array}{l}\text { Turkey } 2011 \text { national I-O table } \\
\text { (prepared by OECD) }\end{array}$ & $\begin{array}{l}\text { Simple LQ approach and survey } \\
\text { based dataset for sectors of } \\
\text { Zonguldak, Karabük, Bartın provinces } \\
\text { (TR81) }\end{array}$ & $\begin{array}{l}\text { Value added, output, salaries and } \\
\text { fixed capital by sector for TR } 81 \\
\text { region. }\end{array}$ \\
\hline $\begin{array}{l}\text { Development Bank of } \\
\text { Turkey - TKB (2014-a) }\end{array}$ & $\begin{array}{l}\text { National level I-O tables (year 2002, } 59 \\
\text { sectors) }\end{array}$ & $\begin{array}{l}\text { National level I-O table generates } \\
\text { direct and total forward and } \\
\text { backward linkages }\end{array}$ & $\begin{array}{l}\text { List the sectors providing the } \\
\text { largest returns on investment in the } \\
\text { Kütahya province. }\end{array}$ \\
\hline $\begin{array}{l}\text { Development Bank of } \\
\text { Turkey - TKB (2014-b) }\end{array}$ & $\begin{array}{l}\text { By using employment-based data } \\
\text { (NACE Rev. 2), } 2002 \text { national level } \\
\text { I-O table ( } 90 \text { sectors) have been } \\
\text { regionalized to TR83 region I-O table. }\end{array}$ & Simple LQ. & $\begin{array}{l}\text { List the sectors providing the largest } \\
\text { returns on investment in the TR83 } \\
\text { (Middle Black Sea Dev. Agency) } \\
\text { region. }\end{array}$ \\
\hline Topcuoğlu (2015) & $\begin{array}{l}\text { Survey of } 59 \text { sectors in } 2014 \text {. Inter- } \\
\text { industrial merchandise flow table of } \\
\text { Turkey (2002). }\end{array}$ & $\begin{array}{l}\text { Inter-industrial merchandise flow } \\
\text { table of Ardahan and Igdır have } \\
\text { been prepared after obtaining input } \\
\text { coefficients matrix. }\end{array}$ & $\begin{array}{l}\text { Forward and backward linkages, } \\
\text { employment and income } \\
\text { multipliers. }\end{array}$ \\
\hline $\begin{array}{l}\text { Aydoğuş et al. } \\
(2015-b)\end{array}$ & $\begin{array}{l}\text { Regional I-O table of İzmir. } 2008 \\
\text { national I-O table. } 36 \text { sub-sectors. }\end{array}$ & $\begin{array}{l}\text { Direct, indirect and final demand } \\
\text { effects of a mega event in Izmir are } \\
\text { quantified using by expenditures and } \\
\text { employment numbers. }\end{array}$ & $\begin{array}{l}\text { Increase in economic activities in } \\
\text { the construction sector and hotels } \\
\text { \& restaurants sector following the } \\
\text { EXPO event. }\end{array}$ \\
\hline $\begin{array}{l}\text { Aydoğuş et al. } \\
(2015-c)\end{array}$ & $\begin{array}{l}\text { A regional I-O table constructed for } \\
\text { İzmir region based on } 2008 \text { national I-O } \\
\text { table and Izmir table. }\end{array}$ & $\begin{array}{l}\text { Focus on hybrid approach for } \\
\text { constructing regional I-O tables. }\end{array}$ & $\begin{array}{l}\text { Important sectors compared to IZKA } \\
(2012) \text { 's previous analysis of the } \\
\text { region. }\end{array}$ \\
\hline $\begin{array}{l}\text { Zafer Regional } \\
\text { Development Agency } \\
\text { - ZEKA (2014) }\end{array}$ & $\begin{array}{l}\text { Employment data (2011) for the } \\
\text { provinces of TR33 (Kütahya, Afyon, } \\
\text { Uşak, Manisa). }\end{array}$ & Simple LQ & $\begin{array}{l}\text { The report focuses on the } \\
\text { manufacturing sectors for the } \\
\text { provinces. }\end{array}$ \\
\hline $\begin{array}{l}\text { Sel and Göktolga } \\
\text { (2016) }\end{array}$ & $\begin{array}{l}\text { I-O tables based on survey data for } 58 \\
\text { companies in Sivas province in } 2014 \text {. }\end{array}$ & $\begin{array}{l}\text { Production, employment and income } \\
\text { multipliers for eight sectors. }\end{array}$ & $\begin{array}{l}\text { List the sectors providing the largest } \\
\text { returns. }\end{array}$ \\
\hline
\end{tabular}

Based on the table above, it is clear that the large majority of past studies have relied on a Simple Location Quotient approach to disaggregate the national interindustry transaction matrix spatially. This paper differs from previous contributions by using various types of LQ, the most recent (2012) national I-O table of Turkey's Statistical Institute in addition to 2014 sales and employment data measured across 33 NACE economic sectors for the region of interest. In the absence of regional output data, we use sales in this manuscript. Any missing values in the regional and national datasets were estimated using sectoral weights.

\section{THE REGION TR33 IN TURKEY}

We focus this paper on the region TR33 that comprises four provinces: Afyonkarahisar, Kütahya, Manisa, Usak. With a population of about three million inhabitants, the value of its export is more than $\$ 5$ billion $^{3}$ (in 2014). TR33 encompasses 22 Organized Industrial Zones and four universities; as such, it is considered as one of the engines of economic growth of Turkey. Its geographic proximity to the nation's major cities, trade centers and ports of Turkey (Istanbul, Izmir, Ankara, Eskisehir, Bursa, Kocaeli, Antalya, and Mersin) have contributed to its development.

${ }^{3}$ For the export numbers of all provinces in Turkey, please visit website of Turkish Exporters Assembly (TiM) at https://www.tim.org.tr/en/ export-export-figures 
Table 2 reports the economic structure of TR33 and compares it with the one of the country. It is based on data from the Turkish Statistical Institute (TUiK). It is obvious that TR 33 is specialized in primary industries (agriculture, forestry, mining), the food-beverage-tobacco sector as well as in some manufacturing sectors (chemical and pharmaceutical products, rubber, metal, automobile) and some services (retail trade). The region has important mineral resources (metallic and non-metallic minerals, coal, lignite, magnesite, marble, silver, antimony, boron etc.). These mineral sources of the region have a large economic potential for the manufacturing sector. At the national level, $1.1 \%$ of the workforce is employed in the mining and quarrying sector, but this rate is $5 \%$ in TR33. Furthermore, TR33 has a greater share of land devoted to agriculture than the national average ( $35 \%$ vs. $30 \%)$. Furthermore, the provinces of Kütahya, Afyon and Manisa have the biggest thermal centers in Turkey. Manufacturing is supported by the presence of 22 organized industrial zones and specializes in porcelain, ceramic, marble, automotive subsidiary industry, textile, machinery and metal industry, agricultural products, food, furniture and microelectronics.

Table 2: Sales and Employment Percentage of Turkey National Level and TR33 Region

\begin{tabular}{|c|c|c|c|c|}
\hline \multirow{2}{*}{ Sectors } & \multicolumn{2}{|c|}{ Employment (\%) } & \multicolumn{2}{|c|}{ Sales (\%) } \\
\hline & TURKEY & TR33 & TURKEY & TR33 \\
\hline 1- Agriculture, Hunting, Forestry and Fishing & 0.06 & 0.36 & 0.05 & 0.57 \\
\hline 2- Mining and Quarrying & 1.02 & 5.09 & 0.89 & 4.76 \\
\hline 3-Food, Beverages and Tobacco & 3.54 & 5.30 & 4.72 & 8.76 \\
\hline 4-Textiles, Textile Products, Leather, other related products & 7.46 & 5.31 & 4.47 & 3.27 \\
\hline 5-Wood and Products of Wood and Cork & 0.53 & 0.72 & 0.35 & 0.30 \\
\hline 6- Paper, paper products, printing and recording services & 0.87 & 0.84 & 0.91 & 0.89 \\
\hline 7-Coke, Refined Petroleum and Nuclear Fuel & 0.06 & 0.05 & 1.36 & 0.20 \\
\hline 8-Chemicals and Chemical Products, pharmaceutics & 0.76 & 1.08 & 1.81 & 2.42 \\
\hline 9- Rubber and Plastics & 1.51 & 2.33 & 1.55 & 2.04 \\
\hline 10- Other Non-Metallic Mineral & 1.79 & 6.99 & 1.75 & 5.23 \\
\hline 11- Basic Metals and Fabricated Metal & 3.40 & 4.08 & 4.85 & 5.55 \\
\hline 12-Computers, electronics and optic products & 0.24 & 0.72 & 0.36 & 1.83 \\
\hline 13-Electrical Equipment & 1.07 & 2.64 & 1.54 & 4.78 \\
\hline 14- Machinery and equipment n.e.c & 1.50 & 1.85 & 1.35 & 1.93 \\
\hline 15-Transport Vehicles (motor vehicles, trailers, etc.) & 1.53 & 2.02 & 2.67 & 3.11 \\
\hline 16- Furniture and other manufactured goods & 1.84 & 0.85 & 0.89 & 0.37 \\
\hline 17- Repair and installation services of machinery and equipment & 0.49 & 0.30 & 0.23 & 0.13 \\
\hline 18-Electricity gas steam air conditioning & 0.63 & 0.87 & 5.08 & 3.97 \\
\hline 19- Natural water, water treatment, sewerage service, waste collection, disposal etc. & 0.77 & 0.45 & 0.62 & 0.41 \\
\hline 20-Constructions and construction works & 11.58 & 8.60 & 7.26 & 4.69 \\
\hline 21-Wholesale and retail trade and repair services of motor vehicles and motorcycles & 2.43 & 2.39 & 3.90 & 2.34 \\
\hline 22-Wholesale trade services, except of motor vehicles and motorcycles & 7.13 & 5.27 & 25.09 & 18.00 \\
\hline 23-Retail trade services, except of motor vehicles and motorcycles & 13.40 & 15.84 & 12.66 & 16.59 \\
\hline 24- Land-Water-air transport services, warehousing, postal and courier & 8.12 & 7.24 & 5.99 & 3.13 \\
\hline 25- Accommodation and food services & 7.49 & 4.78 & 1.99 & 0.96 \\
\hline 26- Publishing services, motion pic. Video, TV prog. Music, telecom, comp. Prog, informa. Serv. & 1.54 & 0.41 & 1.84 & 0.32 \\
\hline 27- Real estate services & 0.45 & 0.31 & 0.34 & 1.01 \\
\hline 28- Legal and accounting services, Architectural and engineering services, Scientific R\&D etc. & 3.96 & 2.54 & 1.73 & 0.71 \\
\hline 29- Rental, leasing, employment, travel, security and investigation, office, business support serv. & 8.09 & 5.62 & 2.02 & 0.73 \\
\hline 30-Education & 2.10 & 1.57 & 0.46 & 0.27 \\
\hline 31- Health, care and social services & 2.31 & 1.58 & 0.77 & 0.55 \\
\hline 32- Creative art, entertainment, library, museum, cultural sporting services etc. & 0.47 & 0.25 & 0.30 & 0.05 \\
\hline 33- Repair services of computers and personal and household goods, other personnel serv. & 1.84 & 1.75 & 0.20 & 0.11 \\
\hline TOTAL (\%) & 100 & 100 & 100 & 100 \\
\hline TOTAL (Values) & 13.558 .322 & 433.061 & $\begin{array}{r}3.500 .264 \\
\text { (million TRY) }\end{array}$ & $\begin{array}{r}89.528 \\
\text { (million TRY) }\end{array}$ \\
\hline
\end{tabular}




\section{VARIOUS TYPES OF LQs AND MULTIPLIERS}

The various types of LQs that will be used in this study are based on studies of Round (1978), Hewings and Jensen (1987), Flegg et al. (1995), McCann and Dewhurst (1998), Flegg and Webber (2000), Okamoto et al. (2005), Smith and Morrison (2007), and Miller and Blair (2009).

In each of the LQs presented in Table 3 below, $x_{i}^{r}$ and $x^{r}$ denote gross output of sector $i$ in region $r$ and total output of all sectors in region $r$ respectively. $x_{i}^{n}$ and $x^{n}$ denote the same concepts but at the national level. Note that the same approach can be used when it is regional employment - instead of output - that is used to regionalize the national input-output matrix.

As noted in Miller (1997), there are a few differences between all the above LQs. In the SLQ and PLQ, the idea is that if their value is less than 1, then the LQ value represents the proportion of total interindustry input requirement that can be supplied (purchased) from within the region. CILQ improves upon the SLQ or PLQ by allowing for differing modifiers given a row of the national matrix. As such, it takes into account the relative importance of both the selling sector $i$ and of the buying sector $j$ at both the regional and the national levels. While the CILQ accounts for the relative size of both the buying and selling sectors, it does not consider the relative size of the local economy compared to the national one like SLQ and PLQ do. As such, the remaining four LQs use a semi-logarithmic transformation to capture, through different means, the increasing propensity of a small area to purchase from other regions. That propensity decreases with the size of the regional economy. Last but not least, the AFLQ version adds to the previous case how one might expect increased sectoral specialization to raise the value of FLQ because of increased intraregional purchases.

Based on the regional input-output matrices that will be approximated through the LQs presented above, we will calculate and report a set of multipliers. For each of them, the calculation starts with capturing the relationship between $n$ economic sectors and by noting as the total output of sector $i$ that satisfies intermediate demand of the sectors $\mathrm{j}\left(\mathrm{x}_{\mathrm{ij}}\right)$ and final demand $\mathrm{f}_{\mathrm{i}}$ :

$$
\mathrm{x}_{\mathrm{i}}=\sum_{\mathrm{j}=1}^{\mathrm{n}} \mathrm{x}_{\mathrm{ij}}+\mathrm{f}_{\mathrm{i}}
$$

We can denote the technical coefficients of production $\left(\mathrm{a}_{\mathrm{ij}}\right)$ as $\mathrm{z}_{\mathrm{ij}} / \mathrm{x}_{\mathrm{j}}$. They correspond to the dollar value of $z_{i j}$ needed for the production of $\$ 1$ of $x_{j}$. Equation (1) can therefore be rewritten as:

$$
\mathrm{x}_{\mathrm{i}}=\sum_{\mathrm{j}=1}^{\mathrm{n}} \mathrm{a}_{\mathrm{ij}} \mathrm{x}_{\mathrm{j}}+\mathrm{f}_{\mathrm{i}}
$$

or $\mathrm{x}=\mathrm{Ax}+\mathrm{f}$ in matrix notation. This equality can be rewritten as

$$
\mathrm{x}=(I-A)^{-1} \mathrm{f}=\sum_{\mathrm{i}} \mathrm{l}_{\mathrm{ij}} \mathrm{f}=\mathrm{Lf}
$$

where $\sum_{\mathrm{i}} \mathrm{l}_{\mathrm{ij}}$ is the output multiplier that will be reported in section 5 . It corresponds to the total output, across all the sectors, produced in order to satisfy $\$ 1$ of final demand in sector $j$. If we note as $e_{j}$ the number of jobs used in the production process of sector $j$, then $E_{j}=e_{j} / x_{j}$ is the direct job input coefficient (per $\$ 1$ of production in $j$ ) which allows us to calculate the total (direct + indirect + induced) employment multiplier as

\begin{tabular}{|c|c|c|}
\hline Types of LQ & Location quotient & $\mathbf{a}_{i j}^{\mathrm{rr}}$ \\
\hline \multirow{2}{*}{$\begin{array}{l}\text { SLQ (Simple Location } \\
\text { Quotient) }\end{array}$} & $\mathrm{x}_{\mathrm{i}}^{\mathrm{r}} / \mathrm{x}^{r}$ & $\left(\mathrm{SLQ} Q_{\mathrm{i}}^{\mathrm{r}}\right) \mathrm{a}_{i j}^{\mathrm{n}}$ if $\mathrm{SLQ}_{\mathrm{i}}^{\mathrm{r}}<1$ \\
\hline & $\overline{x_{i}^{n} / x^{n}}$ & $\mathrm{a}_{i j}^{\mathrm{n}} \quad$ if $\mathrm{SLQ}_{\mathrm{i}}^{\mathrm{r}} \geq 1$ \\
\hline \multirow{3}{*}{$\begin{array}{l}\text { CILQ (Cross-Industry Location } \\
\text { Quotients) }\end{array}$} & & $\left(\operatorname{CILQ}_{\mathrm{ij}}^{\mathrm{r}}\right) \mathrm{a}_{i j}^{\mathrm{n}}$ if $\operatorname{CILQ}_{\mathrm{ij}}^{\mathrm{r}}<1$ \\
\hline & $x_{i}^{r} / x_{i}^{n}$ & $\mathrm{a}_{i j}^{\mathrm{n}} \quad$ if $\operatorname{CILQ}_{\mathrm{ij}}^{\mathrm{r}} \geq 1$ for $i \neq j$ \\
\hline & $\overline{\mathrm{x}_{j}^{\mathrm{r}} / \mathrm{x}_{j}^{\mathrm{n}}}$ & $\begin{array}{cl}\left(\mathrm{SLQ}_{\mathrm{i}}^{\mathrm{r}}\right) \mathrm{a}_{i j}^{\mathrm{n}} & \text { if } \mathrm{SLQ}_{\mathrm{i}}^{\mathrm{r}}<1 \\
\mathrm{a}_{i j}^{\mathrm{n}} & \text { if } \mathrm{SLQ}_{\mathrm{i}}^{\mathrm{r}} \geq 1\end{array}$ for $i=j$ \\
\hline \multirow[t]{2}{*}{ FLQ (Flegg Location Quotient) } & $(\lambda) \operatorname{CILQ}_{\mathrm{ij}}^{\mathrm{r}}$ & $\left(F L Q_{\mathrm{ij}}^{\mathrm{r}}\right) \mathrm{a}_{i j}^{\mathrm{n}}$ if $\mathrm{FLQ}_{\mathrm{ij}}^{\mathrm{r}}<1$ \\
\hline & $\lambda=\left\{\log _{2}\left[1+\left(x_{E}^{r} / x_{E}^{n}\right)\right]\right\}^{\delta}, 0 \leq \delta<1$ & if $F L Q_{\mathrm{ij}}^{\mathrm{r}} \geq 1$ \\
\hline \multirow{2}{*}{$\begin{array}{l}\text { AFLQ (Augmentation of the } \\
\text { FLQ) }\end{array}$} & $\int\left[\log _{2}\left(1+S L Q_{j}^{r}\right)\right] F L Q_{i j}^{r} \quad$ if $\left.S L Q_{j}^{r}>1\right\}$ & $\left(A F L Q_{\mathrm{ij}}^{\mathrm{r}}\right) \mathrm{a}_{i j}^{\mathrm{n}}$ if $\mathrm{FLQ}_{\mathrm{ij}}^{\mathrm{r}}<1$ \\
\hline & $\left\{\quad F L Q_{i j}^{r}\right.$ if $\left.S L Q_{j}^{r} \leq 1\right\}$ & $\mathrm{a}_{i j}^{\mathrm{n}} \quad$ if $\mathrm{FLQ}_{\mathrm{ij}}^{\mathrm{r}} \geq 1$ \\
\hline
\end{tabular}
follows: $\varepsilon_{j}=\sum_{i} E_{i} l_{i j}$.

Table 3: All types of Location Quotients 
Furthermore, the latter multiplier can be used to calculate type 1 employment multipliers that corresponds to the total number of jobs created in the region from the creation of one additional job in the sector of interest: $\varepsilon_{j}^{*}=\sum_{i} E_{i} l_{i j} / E_{j}$.

\section{RESULTS}

We start with the output multipliers. They show how the output of the economy increases following an additional 1 TRY of final demand in a specific sector $i$. Employment Multipliers give results about the change in employment throughout the economy following the same final demand change. Type I employment multipliers, on the other hand, correspond to the total change in employment following the creation of one additional job in a specific sector.

Figures 2-4 below report the output, employment and type I employment multipliers respectively. Each time, the upper figure is based on multipliers calculated on regional sales while the lower figure reports the multipliers based on employment. Due to differences in labor productivity across sectors, one should not be surprised to see slight differences between upper and lower figures. In addition, note that we decided to report only the CILQ, FLQ and AFLQ due to space constraints. For each figure, the complete name of the sector appears in appendix table 1.

According to Figure 2, the sectors displaying the largest 5 Output Multipliers respectively for CILQ based on output are: 1-Transport Vehicles, 2-Rubber and Plastics, 3-Electricity Gas Steam Air Conditioning, 4-Paper, Paper Products, Printing and Recording Services, 5-Basic Metals and Fabricated Metal. The sectors displaying the largest 5 output multipliers respectively for FLQ based on output are: 1-Coke, Refined Petroleum and Nuclear Fuel, 2-Food, Beverages and Tobacco, 3-Accommodation and food services, 4-Wood and Products of Wood and Cork, 5-Electricity Gas Steam Air Conditioning. The sectors displaying the largest 5 output multipliers respectively for AFLQ based on output are: 1-Coke, Refined Petroleum and Nuclear Fuel, 2- Agriculture, Hunting, Forestry and Fishing, 3- Food, Beverages and Tobacco, 4- Computers, Electronics and Optic Products, 5- Accommodation and Food Services

According to Figure 2, the sectors displaying the largest 5 Output Multipliers respectively for CILQ based on employment are: 1- Electricity Gas Steam Air Conditioning, 2- Transport Vehicles, 3- Rubber and Plastics, 4- Machinery and Equipment, 5- Paper, Paper Products, Printing and Recording Services. The sectors displaying
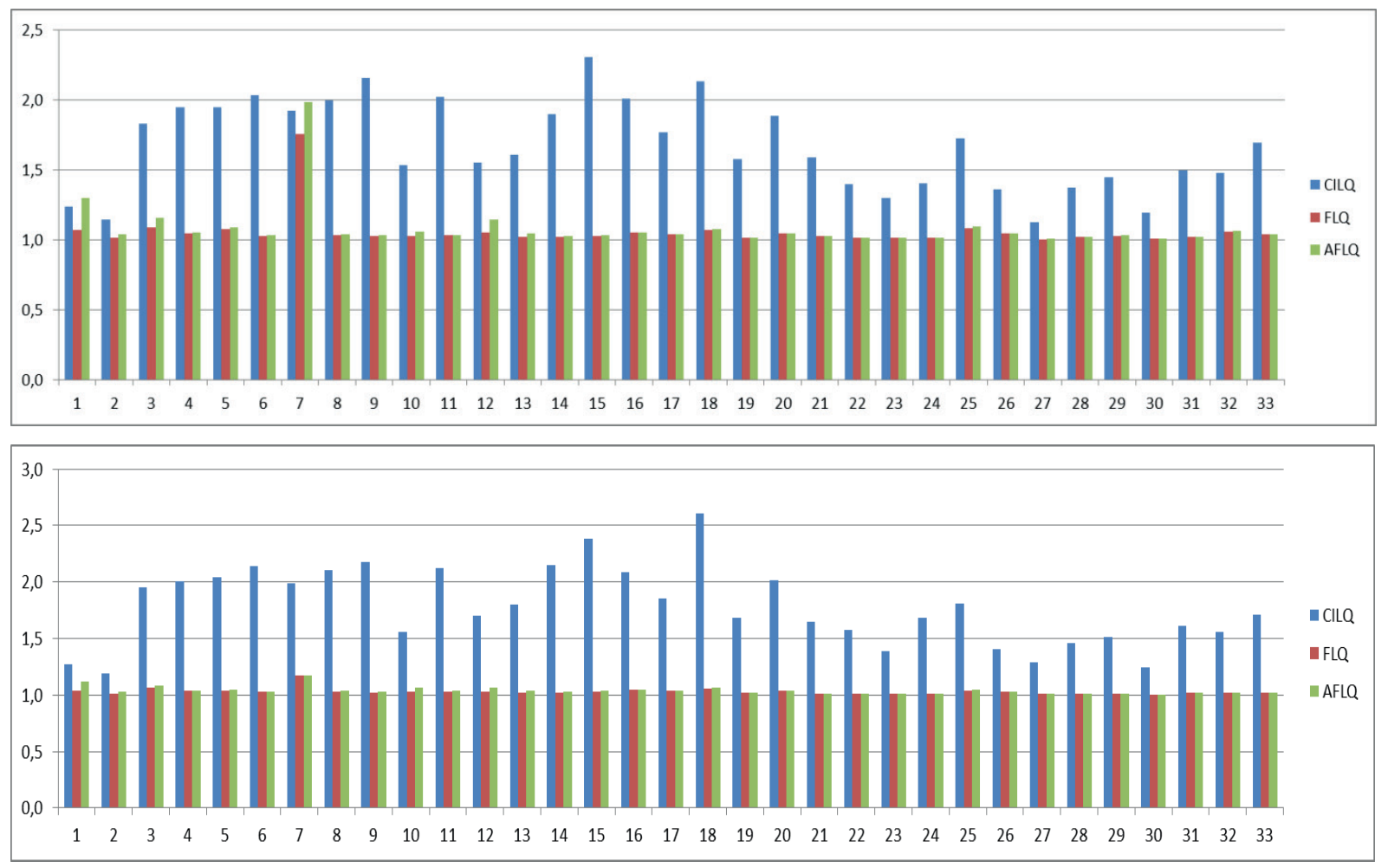

Figure 2: Output multipliers (upper figure: sales, lower figure: employment) 
the largest 5 Output Multipliers respectively for FLQ based on employment are: 1- Coke, Refined Petroleum and Nuclear Fuel, 2- Food, Beverages and Tobacco, 3- electricity gas steam air conditioning, 4- Furniture and Other Manufactured Goods, 5- Accommodation and Food Services. The sectors displaying the largest 5 Output Multipliers respectively for AFLQ based on employment are: 1- Coke, Refined Petroleum and Nuclear Fuel, 2- Agriculture, Hunting, Forestry and Fishing, 3- Food, Beverages and Tobacco, 4- Electricity Gas Steam Air Conditioning, 5- Other Non-Metallic Minerals.

According to Figure 3, the sectors displaying the largest 5 Employment Multipliers respectively for CILQ based on output are: 1- Repair Services of Computers and Personal and Household Goods, Other Personal Services, 2- Rental, Leasing, Employment, Travel, Security and Investigation, Office, Business Support Services, 3- Education, 4- Creative Art, Entertainment, Library, Museum, Cultural Sporting Services Etc., 5- Accommodation and Food Services. The sectors displaying the largest 5 Employment Multipliers respectively for FLQ and AFLQ based on output are the same.

According to Figure 3, the sectors displaying the largest 5 Employment Multipliers respectively for CILQ based on employment are: 1- Repair Services of
Computers and Personal and Household Goods, Other Personal Services, 2- Rental, Leasing, Employment, Travel, Security and Investigation, Office, Business Support Services, 3- Creative Art, Entertainment, Library, Museum, Cultural Sporting Services Etc., 4- Education, 5- Accommodation and Food Services. The sectors displaying the largest 5 Employment Multipliers respectively for FLQ based on employment are: 1- Repair Services of Computers and Personal and Household Goods, Other Personal Services, 2- Rental, Leasing, Employment, Travel, Security and Investigation, Office, Business Support Services, 3- Education, 4- Creative Art, Entertainment, Library, Museum, Cultural Sporting Services Etc., 5- Accommodation and Food Services. The sectors displaying the largest 5 Employment Multipliers respectively for AFLQ based on employment are like FLQ.

According to Figure 4, the sectors displaying the largest 5 Type I employment multipliers based on output respectively for CILQ are: 1- Coke, Refined Petroleum and Nuclear Fuel, 2- Electricity Gas Steam Air Conditioning, 3-Wholesale Trade Services, Except of Motor Vehicles and Motorcycles, 4- Transport Vehicles, 5- Chemicals and Chemical Products, Pharmaceutics. The sectors displaying the largest 5 Type I employment multipliers based on output respectively for FLQ are: 1-
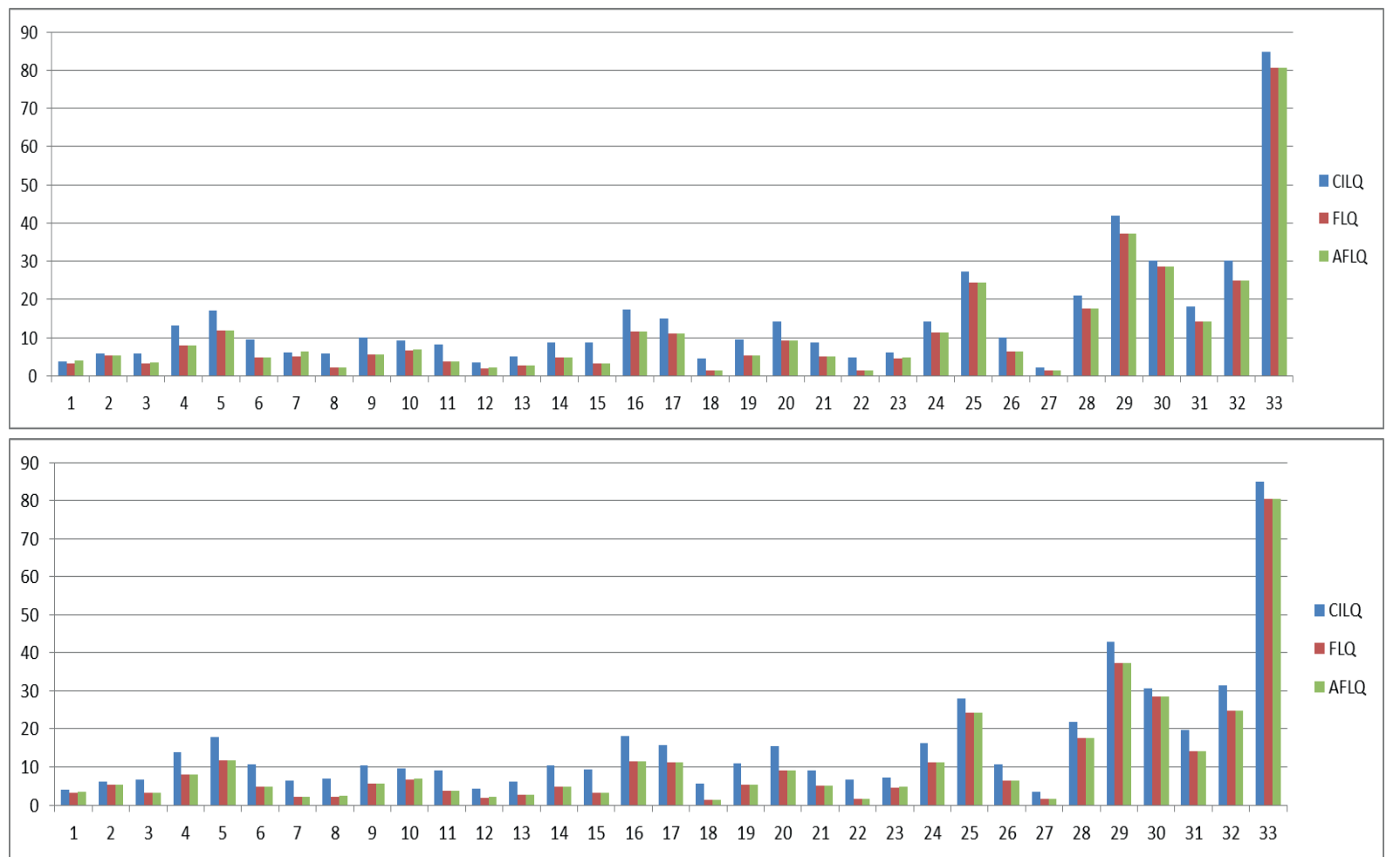

Figure 3: Employment multipliers (upper figure: sales, lower figure: employment) 
Coke, Refined Petroleum and Nuclear Fuel, 2-Electricity Gas Steam Air Conditioning, 3- Food, Beverages and Tobacco, 4- Wholesale Trade Services, Except of Motor Vehicles and Motorcycles, 5- Agriculture, Hunting, Forestry and Fishing. The sectors displaying the largest 5 Type I employment multipliers based on output respectively for AFLQ are: 1- Coke, Refined Petroleum and Nuclear Fuel, 2- Electricity Gas Steam Air Conditioning, 3- Agriculture, Hunting, Forestry and Fishing, 4- Food, Beverages and Tobacco, 5-Computers, Electronics and Optic Products.

According to Figure 4, the sectors displaying the largest 5 Type I employment multipliers based on employment respectively for CILQ are: 1- Coke, Refined Petroleum and Nuclear Fuel, 2- Electricity Gas Steam Air Conditioning, 3-Wholesale Trade Services, Except of Motor Vehicles and Motorcycles, 4- Chemicals and Chemical Products, Pharmaceutics, 5- Transport Vehicles. The sectors displaying the largest 5 Type I employment multipliers based on employment respectively for FLQ are: 1-Coke, Refined Petroleum and Nuclear Fuel, 2- Electricity Gas Steam Air Conditioning, 3-Wholesale Trade Services, Except of Motor Vehicles and Motorcycles, 4-Food, Beverages and Tobacco, 5- Real Estate Services. The sectors displaying the largest 5 Type I employment multipliers based on employment respectively for
AFLQ are: 1- Coke, Refined Petroleum and Nuclear Fuel, 2-Electricity Gas Steam Air Conditioning, 3- Agriculture, Hunting, Forestry and Fishing, 4-Wholesale Trade Services, Except of Motor Vehicles and Motorcycles, 5- Food, Beverages and Tobacco.

Table 2 shows that the region has bigger sales numbers about computers, electronics and optic products, electrical equipment, food, beverages and tobacco, mining and quarrying, other non-metallic mineral, machinery and equipment, transport vehicles (motor vehicles, trailers, etc.), retail trade services, except of motor vehicles and motorcycles etc. There is an important correlation between the findings of the analysis based on regional output and employment and the data in Table 2.

In the future, several factors are expected to increase the sales and the employment in TR33. For instance, the population is expected to increase, the region has already made some important investments in the field of education for some selected sectors (electronics, computers etc.). In addition, the region has experienced an increase in energy production in coal-fired thermal power plants and invests in renewable energy. The construction of new airport and highways in the region positively affects all sectors in recent years.

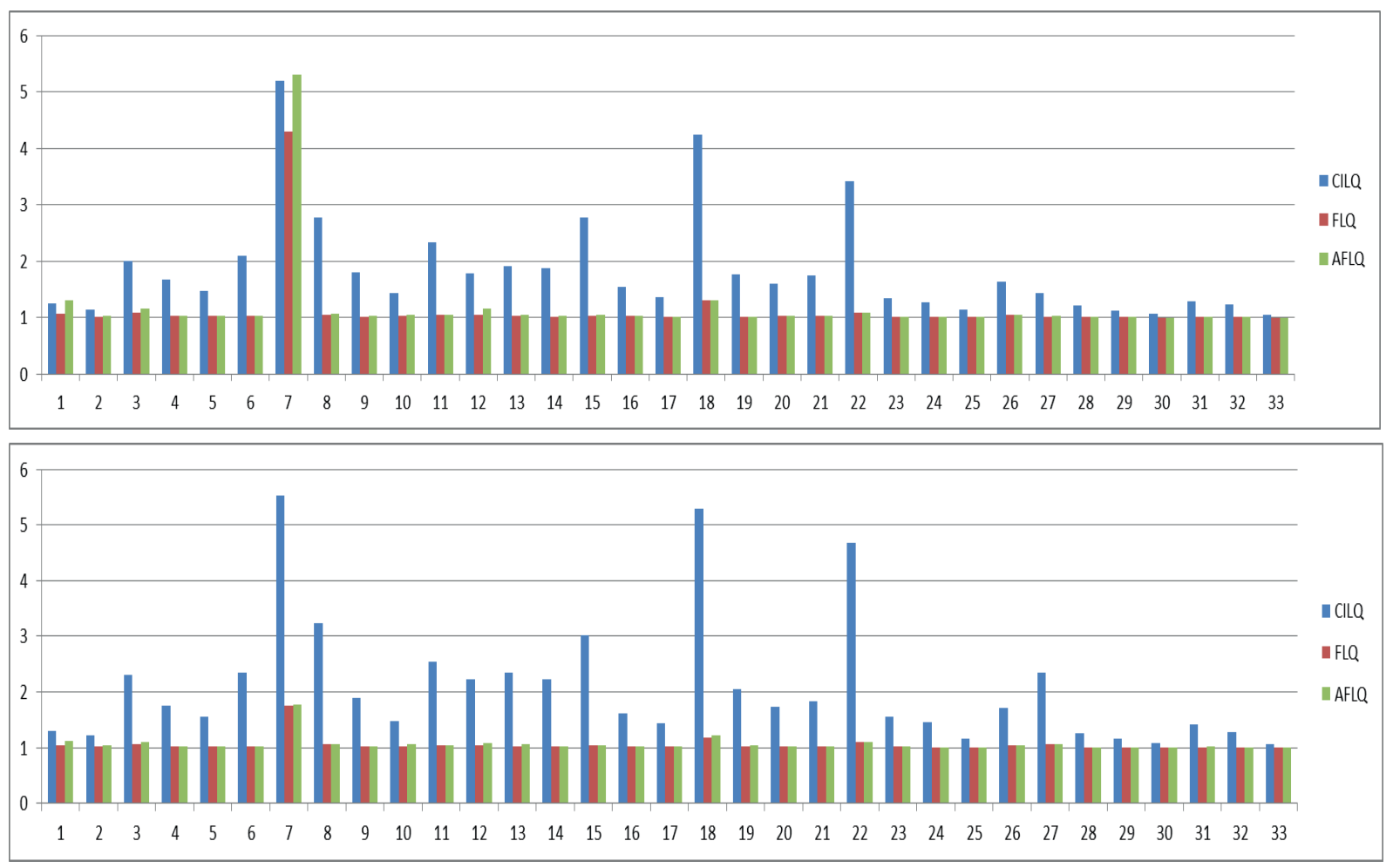

Figure 4: Type I employment multipliers (upper figure: sales, lower figure: employment) 


\section{CONCLUSION}

Like many other developing countries, Turkey does not have the capacity to provide regular input-output matrices of the economic structure of its regions. Yet, the need for regional-level studies has grown in the country due to a persistent problem of regional income disparity. In order to address this problem, several contributions have already offered non-survey techniques aiming at disaggregating national input-output tables and updating them. This paper makes use of these approaches to provide the first input-output study for the region TR33 for the year 2014, the most recent year for which employment and sales data are available locally across producing sectors. In addition, while non-survey techniques have been used in the past in several regions of the country, this manuscript is the first one to go beyond the simple location quotient approach. Indeed, it compares output and employment multipliers based on CILQ, FLQ and AFLQ. Compared to the basic LQ approach, they account for the relative importance of both selling and buying sector (CILQ), the relative size of the local economy (FLQ) or sectoral specialization (AFLQ). While the choice of LQ affects the magnitude of the multipliers calculated, our results indicate that the ranking of the sectoral multipliers is not affected by the LQ choice.

The results indicate that the sectors displaying the largest output multipliers are 3- Food, Beverages and Tobacco, 18- Electricity Gas Steam Air Conditioning, 29- Rental, Leasing, Employment, Travel, Security and Investigation, Office, Business Support Services, 30- Education, and 33- Repair Services of Computers and Personal and Household Goods, Other Personnel Services of sectors, while those displaying the largest employment multipliers are 3- Food, Beverages and Tobacco, 7- Coke, Refined Petroleum and Nuclear Fuel, 18- Electricity Gas Steam Air Conditioning, 22- Wholesale Trade Services, Except of Motor Vehicles and Motorcycles, 29- Rental, Leasing, Employment, Travel, Security and Investigation, Office, Business Support Services, 30- Education, and 33- Repair Services of Computers and Personal and Household Goods, Other Personnel Services of sectors.

Therefore, future development in the region should build on investments in these specific sectors. More precisely, these results should be of interest to the Zafer Development Agency, the Ministry of Science, Industry and Technology, the Small and Medium Enterprises Development Organization (KOSGEB) and other organizations that related to local and regional development in TR33. One way to support these sectors could be for the Organized Industrial Zones to give a parcel of land to the companies that operate in the sectors. In addition, we recommend the local organizations (chambers of commerce and industry, organized industrial zone, provincial directorate of industry and commerce etc.) of the region to prioritize investments on these sectors.

Finally, we believe that government agencies should make their support to various industries conditional on the willingness of the latter to share data on their suppliers and customers. Without systematic and enforced collection of data at the local level, future investment decisions will never be based on better information than the LQ approach presented in this manuscript. 


\section{References}

Atan S. (2011)“A Study into the Inter-sectoral Linkage Structure with Reference to Input-Output Approach: Domestic Product and Imported Intermediate Goods Decomposition", Ekonomik Yaklaşım, 22(80), 59- 78.

Ayas N. (2017) “Import Dependency of Sectors and Major Determinants: an Input Output Analysis", European Journal of Sustainable Development Research, Vol.2, Issue 1, pp. 1-16

Aydın H. (2007) “An Analysis of Input-Output Inter Industry Linkages in the Turkish Economy", 16th International Input-Output Conference, İstanbul, July 02-06, 2007.

Aydoğuş O., Değer Ç., Çalışkan E.T. and Günal G.G. (2015-a) “Import Dependency in Turkey: an Input-Output Analysis", Ege University Working Papers in Economics, Working Paper No: $15 / 02$.

Aydoğuş O., Değer Ç., Çalışkan E.T. and Günal G.G. (2015-b) "Regional Input-Output Analysis of A Mega-Event: Possible Impact of EXPO on Izmir Economy", Anadolu University Journal of Social Sciences, Vol: 15, No: 2,75-84.

Aydoğuş O., Değer Ç., Çalışkan E.T. and Günal G.G. (2015-c) "An Application of the Hybrid Approach to Constructing Regional Input-Output Tables: Case of İzmir, Turkey", İktisat İşletme ve Finans 30(348), 9-34.

Aydoğuş O., Değer Ç., Çalışkan E.T. and Günal G.G. (2017) "An Input-Output Model of Exchange-Rate PassThrough", Economic Systems Research, https://doi. org/10.1080/09535314.2017. 1374243

BAKKA - Western Black Sea Development Agency (2014), TR81 Düzey 2 Bölgesinin Sektörel Yapı ve Rekabet Gücünün Girdi-Çıktı Modeli İle Analizi, http://bakkakutuphane.org/ upload/dokumandosya/Sektorel-YapY-ve-Rekabet-Gucunun-Girdi-CYktY-Modeliyle-Analizi-01.04.2015.23.21.09. pdf

Bon R., Birgonul T. and Ozdogan I. (1999) "An Input-Output Analysis of the Turkish Construction Sector, 1973-1990: A Note", Construction Management and Economics, 17, 543-551.

Çalışkan E.T. and Aydoğuş O. (2011) "Sources of Industrial Growth in Turkish Economy: An Empirical Analysis with Input-Output Model (1985-2002)", Ege Academic Review, 11(4), 499-510.

Celebioglu F. and Dall'erba S. (2010), "Spatial Disparities across the Regions of Turkey: An Exploratory Spatial Data Analysis", the Annals of Regional Science, Vol: 45(2), 379-400.

Davutyan N. (2008) “Estimating the Size of Turkey's Informal Sector: an Expenditure-Based Approach", Journal of Economic Policy Reform, 11(4), 261-271

DBT - Development Bank of Turkey (2012), Türkiye İmalat Sanayiinin Analizi - The Analysis of Turkish Manufacturing Industry, Department of Economic and Social Researches, Ankara.
Dilber İ. (2007) “The Evaluating of Tourism Sector's Effect on Turkish Economy Through Input-Output Table", Yönetim ve Ekonomi, 14(2), 205-220.

Erdoğan E. (2011)“ Multi-regional Social Accounting Matrix and Multiplier Analysis: An Application for Turkish Economy", The Graduate School of Social Sciences of Middle East Technical University (METU), Unpublished Master Thesis, Ankara.

Ersungur Ş.M. and Kızıltan A. (2007) “Türkiye Ekonomisinde İthalata Bağımlılığın Girdi-Çıktı Yöntemiyle Analizi", Atatürk University, Journal of Graduate School of Social Science, 9 (1), 267-278.

Flegg A. T., Webber C. D. and Elliott M. V. (1995) “On the Appropriate Use of Location Quotients in Generating Regional Input-Output Tables", Regional Studies, 29:6, 547-561, DOI Number: 10.1080/00343409512331349173.

Flegg A. T. and Webber C. D. (2000) “Regional Size, Regional Specialization and the FLQ Formula", Regional Studies, 34, 563-569.

Flegg A.T. and Tohmo T. (2013) “Regional Input-Output Tables and the FLQ Formula: A Case Study of Finland", Regional Studies, 47(5), pp. 703-721.

Flegg A.T. and Tohmo T. (2016) “Estimating Regional Input Coefficients and Multipliers: The Use of FLQ is Not a Gamble", Regional Studies, 50(2), pp.310-325.

Flegg A.T., Mastronardi L.J. and Romero C.A. (2016) “Evaluating the FLQ and AFLQ Formulae for Estimating Regional Input Coefficients: Empirical Evidence for the Province of Córdoba, Argentina", Economic Systems Research, 28(1), pp.21-37.

Gezici F. and Hewings G.J.D. (2004) “Regional Convergence and the Economic Performance of Peripheral Areas in Turkey", Review of Urban \& Regional Development Studies, Vol. 16, No. 2, pp.113-132.

Günçavdı Ö. and Küçükçifçi S. (2008) “Openness to Trade and Structural Changes in the Sources of Economic Growth and Labour Demand in Turkey", MPRA Paper No. 9624, http:// mpra.ub.uni-muenchen.de/9624/.

Günçavdı Ö., Küçükçifçi S. and McKay A. (2003) “Adjustment, Stabilization and the Analysis of the Employment Structure in Turkey: An Input-Output Approach", Economics of Planning, 36, 315-331.

Hewings G.J.D. and Jensen R.C. (1987) Handbook of Regional and Urban Economics, Volume 1 (Regional Economics), 1st Edition, Editor: Peter Nijkamp, North Holland Press, Netherlands.

IIlhan B. and Yaman H. (2011) "A Comparative Input-Output Analysis of the Construction Sector in Turkey and EU Countries", Engineering, Construction and Architectural Management, 18 (3), 248-265. 
IZKA-İzmir Regional Development Agency (2012) İzmir Bölgesi Girdi-Çıktı Analizi, http://www.izka.org.tr/files/ppkb/ Izmir_Bolgesel_GC_Modeli_Raporu_web.pdf

Karkacier O. and Goktolga Z.G.(2005) “Input-Output Analysis of Energy Use in Agriculture", Energy Conversion and Management, 46, 1513-1521.

Kaya A.A. (2006) "Regional Specialization and Location of Industrial Activity in Turkey", Regional Studies Association International Conference, 8th and 9th June 2006, Leuven, Belgium.

Kızıltan A. and Ersungur Ş.M. (2005) "Türkiye Ekonomisinde Sektörlerin İstihdama Etkisindeki Değişim: Girdi-Çıktı Yaklaşımıyla Bir Uygulama", Atatürk University, Journal of Economics and Administrative Sciences, 19(2), 31-47.

Lagendijk A., Kayasu S. and Yasar S. (2009) "The Role of Regional Development Agencies in Turkey: From Implementing EU Directives To Supporting Regional Business Communities?", European Urban and Regional Studies, 16 (4), 383-396.

McCann P. and Dewhurst J. H. L. (1998) “Regional Size, Industrial Location and Input-Output Expenditure Coefficients", Regional Studies, 32, 435-444.

Miller R. (1997) Regional and Interregional Input-output Analysis , in: Isard W., Aziz I., Drennen M., Miller R., Saltzman S., Thorbecke E. (Eds.), Methods of Interregional and Regional Analysis, pp. 41-133, Ashgate Publishing: Regional Science Studies Series.

Miller R.E. and Blair P.D. (2009) Input-Output Analysis - Foundations and Extensions, Cambridge University Press, NewYork.

Okamoto N., Zhang Y. and Zhao K. (2005)“Non-Survey Methods for Estimating Regional and Interregional Input-Output Multipliers", in book: Spatial Structure and Regional Development in China: An Interregional Input-Output Approach (Edited by Nobuhiro Okamoto and Takeo Ihara), Palgrave Macmillan, New York.

Round J. I. (1978) “An Interregional Input-Output Approach to the Evaluation of Non-survey Methods" Journal of Regional Science, 18(2), 179-194.

Sarışık M., Akova O., Türkay O. and Sarı D. (2011)" An Evaluation of the Impact of Tourism on Turkey's Economy by Input-Output Analysis", International Conference on Eurasian Economies, 12-14 October 2011 - Bishkek, KYRGYZSTAN, 210-216.

Sel A. and Göktolga Z.G. (2016) "Sivas İli Temel Sektörlerinin Girdi Çikti Yöntemiyle Analizi", Cumhuriyet Üniversitesi, İktisadi ve İdari Bilimler Dergisi, Vol. 17(2), 1-21.

Smith P. and Morrison W.I. (2007) Simulating the Urban Economy - Experiments with Input-Output Techniques, Routledge Publishing, UK.
SPO (2000) Main Plan of East Anatolia Project (Strategy and Reconstruction Scenarios), Ankara, http://www.dap.gov.tr/ content/DAP/DAPANAPLAN/PDF/ana_plan.pdf

Taşçı K. (2013) "The Importance of ICT Sector for Turkish Economy by Employing Input-Output Analysis Approach", Akademik Bakış Dergisi, 34, 1-20.

Tekin A. B. and Evcim H.U. (2011) "Input-Output Structure of Turkish Agriculture", Bulgarian Journal of Agricultural Science, 17 (2), 258-268.

The Law on the Establishment, Coordination and Task of Development Agencies, Law no: 5449, January 25, 2006.

The Law on the Turkish Statistics, Law no: 5429, October 11, 2005.

Development Bank of Turkey - TKB (2014-a) "Kütahya İli Potansiyel Yatırım Konuları Araştırması", (Prepared by Fulya Bayraktar and Mehmet Emin Karaca; Coordinated by Oktay Küçükkiremitçi, Ömür Genç and Mustafa Şimşek), March, Ankara, Turkey.

Development Bank of Turkey - TKB (2014-b) “TR83 Bölgesi Uygun Yatırım Alanları Araştırması - Samsun İli", (Prepared by Fulya Bayraktar and Faruk Sekmen; Coordinated by Oktay Küçükkiremitçi, Ömür Genç, Mustafa Şimşek and Belgin ÖZOĞUL), December, Ankara, Turkey.

TiM - Turkish Exporters Assembly (2014), https://www.tim.org. tr/en/export-export-figures

Topcuoğlu A. (2015) “Comparative Structural Analysis of Ardahan and Iğdır: an Application through Static Input-Output Model", Ph.D. Dissertation (Advisor: Ş. Mustafa Ersungur), Atatürk University Social Science Institute Department of Economics, Erzurum.

TUiK - Turkish Statistical Institute (2010), Annual Industry and Service Statistics.

TUiK - Turkish Statistical Institute (2017) National Level I-O Tables, http://www.turkstat.gov.tr/PreTablo. do?alt_id=1021

TUiK - Turkish Statistical Institute (2017) Some Basic Indicators by Local Units, http://www.tuik.gov.tr/MicroVeri/ YSH_2015/turkce/downloads/10.yerel-birim-faaliyetlerine-goere-bazii-teme.xls

Zafer Development Agency - ZEKA (2014) “Determination and Analysis of Manufacturing Structure and Level of TR33 Region (originally in Turkish:TR33 Bölgesinin Üretim Yapısının ve Düzeyinin Tespiti ve Analizi), Kütahya, Turkey.

Zafer Development Agency - ZEKA (2016) “Analysis of Current Situation in TR33" (originally in Turkish: Mevcut Durum Analizi), Kütahya, Turkey.

Zafer Development Agency - ZEKA (2017) “TR33 Region Info", http://www.zafer.org.tr/eng/tr33region. html

Zengin H. and Tütüncü A. (2016) “Kayıtdışı Ekonominin Tahmini ve Vergi Gelirleri ile Arasındaki İlişki", Finans Politik \& Ekonomik Yorumlar, 53, 73-86. 


\section{APPENDIX TABLE 1: Sector Names and Codes}

\begin{tabular}{|c|c|c|}
\hline Sector Name & Sector Codes & No \\
\hline Agriculture, Hunting, Forestry and Fishing & A01-A03 & 1 \\
\hline Mining and Quarrying & B5-B9 & 2 \\
\hline Food, Beverages and Tobacco & $\mathrm{C} 10-\mathrm{C} 12$ & 3 \\
\hline Textiles, Textile Products, Leather, other related products & $\mathrm{C} 13-\mathrm{C} 15$ & 4 \\
\hline Wood and Products of Wood and Cork & C16 & 5 \\
\hline Paper, paper products, printing and recording services & $\mathrm{C} 17-\mathrm{C} 18$ & 6 \\
\hline Coke, Refined Petroleum and Nuclear Fuel & C19 & 7 \\
\hline Chemicals and Chemical Products, pharmaceutics & $\mathrm{C} 20-\mathrm{C} 21$ & 8 \\
\hline Rubber and Plastics & $\mathrm{C} 22$ & 9 \\
\hline Other Non-Metallic Mineral & $\mathrm{C} 23$ & 10 \\
\hline Basic Metals and Fabricated Metal & $\mathrm{C} 24-\mathrm{C} 25$ & 11 \\
\hline Computers, electronics and optic products & $\mathrm{C} 26$ & 12 \\
\hline Electrical Equipment & $\mathrm{C} 27$ & 13 \\
\hline machinery and equipment n.e.c & $\mathrm{C} 28$ & 14 \\
\hline Transport Vehicles (motor vehicles, trailers, etc.) & $\mathrm{C} 29-\mathrm{C} 30$ & 15 \\
\hline Furniture and other manufactured goods & C31-C32 & 16 \\
\hline Repair and installation services of machinery and equipment & C33 & 17 \\
\hline electricity gas steam air conditioning & D35 & 18 \\
\hline Natural water, water treatment, sewerage service, waste collection, disposal etc. & E36-E39 & 19 \\
\hline Constructions and construction works & F41-F43 & 20 \\
\hline Wholesale and retail trade and repair services of motor vehicles and motorcycles & G45 & 21 \\
\hline Wholesale trade services, except of motor vehicles and motorcycles & G46 & 22 \\
\hline Retail trade services, except of motor vehicles and motorcycles & G47 & 23 \\
\hline Land-Water-air transport services, warehousing, postal and courier & $\mathrm{H} 49-\mathrm{H} 53$ & 24 \\
\hline Accommodation and food services & $155-156$ & 25 \\
\hline Publishing services, motion pic. Video, TV prog. Music, telecom, comp. Prog, informa. Serv & J58-J63 & 26 \\
\hline Real estate services & L68 B & 27 \\
\hline Legal and accounting services, Architectural and engineering services, Scientific R\&D etc. & M69-M75 & 28 \\
\hline rental, leasing, employment, travel, security and investigation, office, business support serv. & N77-N82 & 29 \\
\hline Education & P85 & 30 \\
\hline Health, care and social services & Q86-Q88 & 31 \\
\hline Creative art, entertainment, library, museum, cultural sporting services etc. & R90-R93 & 32 \\
\hline Repair services of computers and personal and household goods, other personnel serv. & S95-S96 & 33 \\
\hline
\end{tabular}

